\title{
Analysis of Students' Factors Influencing the Integration of E- Learning in Higher Education. Case Study:University of Tetovo
}

\author{
Gazmend Xhaferi \\ University of Tetovo, Macedonia
}

Rovena Bahiti

University of Tirana

Arta Farizi

SEE University, Tetovo, Macedonia

\section{Abstract}

E-Learning is an Important tool for delivery, interaction, and facilitation of both teaching and learning processes in higher education. The purpose of this paper is the investigation of students' attitudes about the use of ICT and integration of e-learning at the University of Tetovo. This study also examines the factors contributing to students' attitudes towards E-Learning as well as identifying the important factors to its successful integration. The conceptual research framework of e-learning integration, which is used in the analysis, is based on the technology acceptance model (TAM). The research developed an extended TAM model (Technology Acceptance Model for E-learning) for predicting the intention to integrate E-Learning using the constructs of the TAM. Statistical analysis was conducted to assess student attitudes towards integrationof elearning, and to analyses the relationships between their attitudes and their demographic characteristics, Perception about ICT,ICT experience and ICT Competence that predict the integration of e-learning. Questionnaire was used to collect data from a sample of 314 undergraduate students from different program studies. Statistical techniques are used for the analyses of data. Factor analysis was used to validate the instrument, however; the partial least square method was used to test the model for the study, moreover; stepwise regression analysis were used to test the hypotheses of the study. The findings indicate that students have an important role in prediction of the integration of E-Learning in University of Tetovo. The reported findings might be of interest to institution, academics administrators, and decision-makers involved in planning, developing and implementation of e-learning in University of Tetovo and similar universities in developing countries.

Keywords: Atittude, TAM, ICT competence, ICT experience, ICT perception, Prediction 


\section{Introduction}

The role of information, communication and technologies (ICT) in learning and teaching process is becoming more and more important tool. One of the most significant developments in the use of information technology in universities in the last decade has been the integration and use of e-learning systems to support the processes of teaching and learning. E-Learning is a concept derived from the use of information and communication technologies (ICTs) to revise and transform traditional teaching and learning models and practices has evolved in the past decade(OECD, 2005). Numerous researchers have stated that the role of student in the process of integration technology in the teaching and learning process has been crucial (Chen, 2010; Park, 2009; Teo \& van Schaik, 2009; Wong \& Teo, 2009). Student characteristics are regarded as a critical success factor in e-learning in developing countries(Bhuasiri et al., 2012).These characteristics include computer self-efficacy, Internet self-efficacy, computer experience, Internet experience, computer anxiety, and attitudes toward e-learning. Students' attitudes towards E-Learning are dependent on access to ICT as well as the perception of the usefulness of E-Learning in the educational process (Kirkwood \& Price, 2005). Students' attitudes are also influenced by their previous experience and skills with ICT and E-Learning. Student attitudes towards ICT and integration of e-learning at the University of Tetovo as one of public university in Macedonia where the teaching and learning language is Albanian language have not been investigated before. Also, this study investigates the factors that influencing students' attitudes about the integration of e-learning in learning and teaching process. Consequently, this paper aimed to assess the perception of students' towards integrating e-learning into teaching and learning at University of Tetovo. In this study is used the Technology Acceptance Model (TAM), which is a model widely used in the studies about the acceptance of technology(Davis, 1993).This study proposes the use of an extended TAM model, which determines perception about technology, technology compentence and technology experience are primary factors influencing students' attitude and the intention to adopt the technology.Furthermore, knowing the students' attitudes about ICT and integration of the e-learning,and understanding the factors that influence students' attitudes about integration of the e-learning can help academic administrators and managers to create mechanisms for attracting more students to adopt this learning environment.

\section{Research Model and Hypothesis}

The objective of this research was to investigate the factors that influence the student's attitudes towards using ICT and integration of e-learning system at the University of Tetovo. However, for the purpose of model development for this research, the TAM model will be expanded including these external variables: Perception about ICT (perceived usefulness of technology, perceived ease of use of technology), ICT Experience (technology usage and experience), and ICT Competence (level of knowledge and skills about technology), which all have proven to be important 
factors that influence lecturers behavioral intentions toward adopting a new system. The research model is presented in Figure (2).

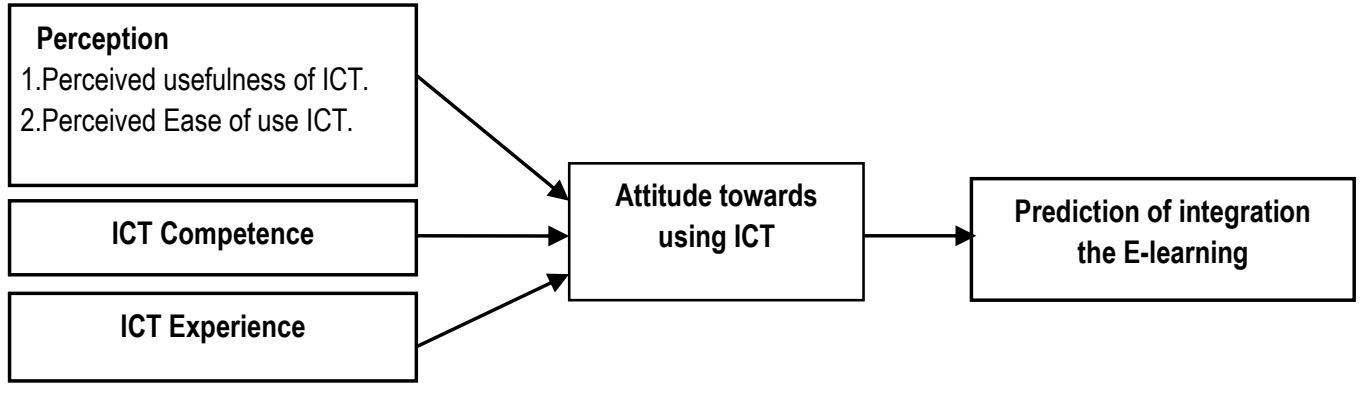

Figure 2: Research Model

The study is divided into two phases. The first stage involved taking the variable Attitude as the dependent variable and all other variables as the independent variables (Perception, Competence and Experience).

H1.Students Perceptions about ICT have a positive influence ahead Attitude towards using ICT .

H2.Students ICT Competence have a positive influence ahead Attitude towards using ICT. H3.Students ICT Experience has a positive influence ahead Attitude towards using ICT.

The second stage involved taking the variable E-learning Prediction (shortened for Prediction of Adoption of E-learning) as the dependent variable and all other variables as the independent variables.

H4.The perception of students on the technology has a positive influence ahead the Prediction of e-learning.

H5. Students ICT Competence has a positive influence ahead the Prediction of integration e-learning.

H6. Students ICT Experience has a positive influence ahead the Prediction of integration e-learning.

H7.Students Attitudes towards ICT has a positive influence ahead the Prediction of integration e-learning.

\section{Research Methodology}

For this study was used a questionnaire to obtained data across six sections consisting of: 1) demographiccharacteristics of students ; 2)Perception abouttechnology (perceived usefulness and perceived ease of use)(14 questions) ;3) ICT Competence (level of knowledge and skills about technology) (7 questions)4) ICT Experience (Technology usage and experience)(6 questions); 5) Attitude towards ICT in teaching 
and learning process (6 questions); and 6) prediction of E-Learning(12 questions).Data was collected from 314 undergraduate students of different faculty at University of Tetovo. Data for this research was collected through a survey instrument and analysed using Statistical Package for the Social Sciences (SPSS). Descriptive statistics were used to summarize and describe the data collected from the respondents. Furthermore, factor analysis was also performed to identify key factors that are likely to influence integration.In addition, The reliability of the quantitative data in this study was determined by finding Cronbach's Alpha. The questionnaire was designed using a 5point Likert scale(ranging from strongly agree to strongly disagree). Finally, Pearson Product Moment correlations were used to examine the relationships between the variables that were measured on the interval scale.

\section{Data Analysis and Results}

Data was analysed using Statistical Package for Social Science (SPSS) software. Descriptive statistics such as median, frequency, and percentage are used for analysis. Demographic characteristics of studetns are given in Table 1.

\begin{tabular}{|c|c|c|c|c|}
\hline Charachteristics & \multicolumn{2}{|c|}{ Category } & \multicolumn{2}{|c|}{\begin{tabular}{l|l} 
Frequency $\&$ Percentage in \\
the Study \\
$\mathrm{N}$ & $\%$
\end{tabular}} \\
\hline \multirow{3}{*}{$\begin{array}{l}\text { Gender } \\
\text { Study program } \\
\text { Year of study }\end{array}$} & \multicolumn{2}{|l|}{$\begin{array}{l}\text { Male } \\
\text { Female }\end{array}$} & $\begin{array}{l}126 \\
188\end{array}$ & $\begin{array}{l}40.1 \% \\
59.9 \%\end{array}$ \\
\hline & $\begin{array}{l}\text { Informa } \\
\text { Mathem } \\
\text { Physics } \\
\text { Chemist } \\
\text { Biology } \\
\text { Marketi } \\
\text { Econom } \\
\text { Finance }\end{array}$ & & $\begin{array}{l}72 \\
68 \\
14 \\
44 \\
18 \\
13 \\
40 \\
45\end{array}$ & $\begin{array}{l}23.9 \\
21.7 \\
4.5 \\
14.0 \\
5.73 \\
4.13 \\
12.74 \\
14.3\end{array}$ \\
\hline & \multicolumn{2}{|l|}{$\begin{array}{l}\text { first } \\
\text { second } \\
\text { third } \\
\text { forth }\end{array}$} & $\begin{array}{l}89 \\
81 \\
93 \\
51\end{array}$ & $\begin{array}{l}28.3 \\
25.8 \\
29.6 \\
16.2\end{array}$ \\
\hline \multirow{2}{*}{\multicolumn{2}{|c|}{ Use E-learning as Learning Tool }} & Yes & 117 & 37.3 \\
\hline & & No & & 62.7 \\
\hline \multicolumn{3}{|c|}{ Total No. of students } & 314 & 100 \\
\hline
\end{tabular}

Table1.students' demographic characteristics 
Also the descriptive statistics showed that the majority of participants indicate positive responses to the constructs that are measured in this study (See Table 2). All means were above midpoint and the standard deviations range from 3.58 and 8.25.

\begin{tabular}{|l|l|l|l|l|l|}
\hline Factors & $\begin{array}{l}\text { N. of } \\
\text { Question }\end{array}$ & Min & Max & Mean & St.d dev. \\
\hline PERCEPTION about ICT & 14 & 24 & 70 & 53.0288 & 8.25 \\
\hline ICT COMPETENCE & 5 & 4 & 25 & 16.6997 & 3.58 \\
\hline ICT EXPERIENCE & 7 & 7 & 34 & 16.3671 & 5.75 \\
\hline ATTITUDE towards ICT & 6 & 4 & 30 & 21.7604 & 4.94 \\
\hline $\begin{array}{l}\text { PREDICTION of E- } \\
\text { Learning }\end{array}$ & 11 & 9 & 54 & 37.8814 & 7.00 \\
\hline
\end{tabular}

Table 2: Descriptive Statistics of the constructs

The reliability analysis measured the internal validity and consistency of items used for each construct. Calculating Cronbach's alpha coefficient tested the factor reliability. Recommended that a Cronbach alpha value of 0.7 and greater is acceptable(DunnRanking,2004). Cronbach's alpha values for all factors are above 0.70 (see Table 3) indicating that all measures employed in this study demonstrate a satisfactory internal consistency. Therefore, the survey is considered a reliable measurement instrument.

\begin{tabular}{|l|l|l|}
\hline Construct & Cronbach Alpha & Number of Items \\
\hline PERCEPTION about ICT & 0.833 & 14 \\
\hline ICT COPETENCE & 0.668 & 5 \\
\hline ICT EXPERIENCE & 0.889 & 7 \\
\hline ATTITUDE towards ICT & 0.829 & 6 \\
\hline PREDICTION of integration E-Learning & 0.817 & 11 \\
\hline
\end{tabular}

Table 3: CronbachAlpha Coefficients for Constructs with Multiple Items

In this study were used the Pearson correlation coefficients to measure the relationships between the variables. Correlation analysis answers the question if there exists association or correlation between the two (or more) variables and to what degree. The correlation coefficients were interpreted by descriptors, negligible $=0.00$ to 0.09 ; low $=0.10$ to 0.29 ; moderate $=0.30$ to 0.49 ; substantial $=0.50$ to 0.69 ; very strong $=0.70$ to 1.00 ( Davis,1971). The correlation matrix is presented in Table 4. 


\begin{tabular}{|l|l|l|l|l|l|}
\hline & $\begin{array}{l}\text { PERCEP } \\
\text { TION } \\
\text { about } \\
\text { ICT }\end{array}$ & $\begin{array}{l}\text { ICT } \\
\text { COMPETE } \\
\text { NCE }\end{array}$ & $\begin{array}{l}\text { ICTEXPE } \\
\text { RIENCE }\end{array}$ & $\begin{array}{l}\text { ATTITU } \\
\text { DE } \\
\text { towards } \\
\text { ICT }\end{array}$ & $\begin{array}{l}\text { PREDICTIO } \\
\text { N of } \\
\text { integration } \\
\text { E-L }\end{array}$ \\
\hline PERCEPTION about ICT & & & & & \\
\hline ICT COMPETENCE & .407 & & & & \\
\hline ICT EXPERIENCE & .379 & .314 & & & \\
\hline ATTITUDE towards ICT & .506 & .410 & .312 & & \\
\hline $\begin{array}{l}\text { PREDICTION } \\
\text { integration E-L }\end{array}$ & .379 & .372 & .223 & .479 & \\
\hline
\end{tabular}

Table 4. The correlation matrix of factors ( ${ }^{* *}$. Correlation is significant at the 0.01 level (2-tailed)).

For testing hypothesis is used a linear regression analysis that was undertaken using the dependent variables for integration e-learning using the method enter. In the table 5 are summaries the results obtained from testing the research hypotheses. The results confirmed that there was a statistical correlation between the predicted directions of the research model. Overall, all of seven hypotheses were supported by the collected data. After the examination of each of the seven hypotheses was made.

\begin{tabular}{|l|l|l|l|l|l|l|}
\hline $\begin{array}{l}\text { Research } \\
\text { Hypothesis }\end{array}$ & Path & $\begin{array}{l}\text { Standardized } \\
\text { Path } \\
\text { Coefficient } \\
\text { (Beta) }\end{array}$ & $\begin{array}{l}\text { t- } \\
\text { value }\end{array}$ & $\begin{array}{l}\text { Signifi } \\
\text { cance }\end{array}$ & $\begin{array}{l}\text { Results } \\
\text { Significanc } \\
\text { (p) }\end{array}$ & $\mathrm{R}^{2}$ \\
\hline H1 & $\mathrm{P} \rightarrow \mathrm{A}$ & .496 & 10.10 & .000 & Supported & .246 \\
\hline H2 & $\mathrm{E} \rightarrow \mathrm{A}$ & .304 & 5.643 & .000 & Supported & .093 \\
\hline H3 & $\mathrm{C} \rightarrow \mathrm{A}$ & .410 & 7.950 & .000 & Supported & .168 \\
\hline H4 & $\mathrm{P} \rightarrow$ PEL & .371 & 7.037 & .000 & Supported & .137 \\
\hline H5 & E $\rightarrow$ PEL & .204 & 3.674 & .000 & Supported & .042 \\
\hline H6 & C $\rightarrow$ PEL & .350 & 6.597 & .000 & Supported & .123 \\
\hline H7 & A $\rightarrow$ PEL & .453 & 8.955 & .000 & Supported & .205 \\
\hline
\end{tabular}

Table 5: Summary of the Hypothesis Testing

To determine a goodness-of-fit measure which determines how well the statistical model fits the set of observations is used the linear regression. The analysis of the model used in this study is examined the goodness of fit among the Students with the analysis indicating that the model accounted for approximately $25.1 \%$ of the variation $\left(\mathrm{R}^{2}=.251\right)$. 


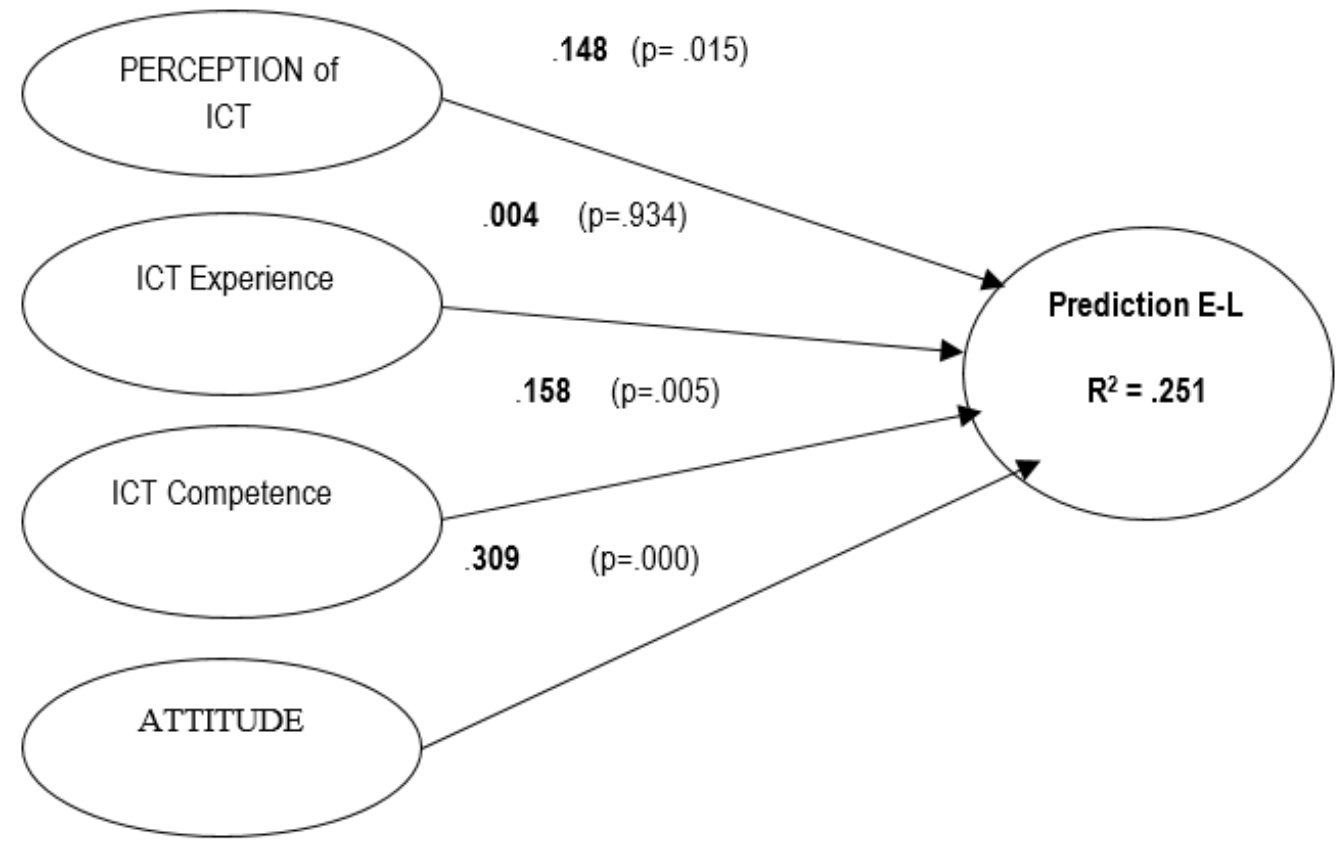

Figure 4: Results of Beta values and results for Students $\mathrm{R}^{2}$

The analysis of the model using SEM and the SPSS software for the linear regression indicated that the model explains approximately $25 \%$ of the variance in the prediction or intention to use E-Learning from the students $\left(\mathrm{R}^{2}=25.1 \%\right)$. The results of our model for the goodness-of-fit for the model are different to the findings of others researchers investigating, for instance,in (Park, 2009) the percentage for the goodness-of-fit was ( $\mathrm{R}^{2}$ $=66 \%)$, and in (Mazen et al, 2013) the percentage for the goodness-of-fit was $\left(R^{2}=59 \%\right)$.

\section{Findings and Discussion}

The purpose of this study was to analyze the attitudes of students towards technologies in the learning process and the factors that influence their decisions to adopt and integrate these technologies into teaching process.The aim of the analysis was to determine the degree to which these three variables and include the construct of Attitude, which is considered an intermediate variable influence the Prediction of the integration E-Learning. From the obtained results and based to analysis we can conclude that not all factors added to the expanded TAM model have significant effect on Prediction of the E-Learning.Results show that only the variables of Attitudes, Perception about ICT and ICT Competence had a statistically significant effect on the Prediction of E-L. The findings about factor ICT Experience, show that this factor is not statistically significant that is contrary of the findings of others previous researchers. The analysis as shown in Table 5 indicated that the variable of ICT Experience did not account for a significant amount of the variance in Prediction of integration e-learning 
based on goodness-of-fit (ICT Experience $\mathrm{R}^{2}=.042$ ), while a weak correlation was found. Findings from the study demonstrate that there was a statistically significant moderate association between variables ICT Competence and Prediction of integration E-leaning. Thus, it implies that students with knowledge and skills in ICT played a significant role in constructing positive attitudes towards integration of e-learning and means thatstudents whose have skills in ICT and greater level of knowledge about ICT, have more positive intention towards integration of e-learning in the teaching process. Also, results obtained that there was a statistically significant moderate association between variables Perception about ICT(the variable is composed of perceived usefulness of ICT and perceived ease of use of ICT) and Prediction of integration E-leaning. On the other hand, there was a low association between variables ICT Experience and Prediction of the integration of e-learning in teaching and learning process.

Another findings from the analysis is that, the individual factors have a moderate relationship with Attitude, but the three taken together have a substantial association. Attitude itself is moderately associated with E-learning Prediction. The finding of a moderate relationship between positive Attitude towards ICT and prediction of ELearning is differently to the findings of researchers in other nations examining the relationship between attitude and adoption of E-Learning where the relationship is strong. Therefore, from the analysis and results reported here are consistent with outcomes of similar studies, noting that attitude was a key factor in determining technology adoption (Teo, Lee \& Chai, 2008, Teo, 2012). The findings also conform to the proposition of the model, that attitude is the most significant predictor for the intention to adopt a technology (Shin \& Kim, 2008).

\section{Conclusion}

This study demonstrated the importance of students' Perception about ICT, ICT Experience and ICT Competence for attitudes towards integration E-Learning in teaching process. Greater part of students in this study believed and has positive attitude that using ICT in learning would significantly contribute to the efficacy and effectiveness of their teaching. Findings from this study suggest that students' positive attitude towards ICT and e-learning is essential if University of Tetovo need to successfully transform its education systems from the current classroom face-to-face methods to elearning. In conclusion can say that students are one of the key stakeholders of education and their attitudes towards using ICT and also their skills, experience and perception about ICThas a significant impact on prediction of integration of e-learning in learning and teaching process. Identification of attitudes and factors influence integration of elearning would provide useful knowledge for education stakeholders and higher institution which can help in planning and increasing effectiveness of the adoption of elearning in higher education. The research model and the findings of the study can serve as a model for developing framework and which stockholders and factors to take into consideration for integrating e-leanirng into the teaching process as a learning method 
for the students of the University of Tetovo as well and other universities in the developing countries.

\section{References}

[1] OECD (2005), E-learning in Tertiary Education: Where Do we Stand? Paris.

[2] Bhuasiri, W., Xaymoungkhoun, O., Zo, H., Rho, J.J. and Ciganek, A.P. (2012), "Critical success factors for e-learning in developing countries: A comparative analysis between ICT experts and faculty", Computers \& Education, 58(2), 843855.

[3] Kirkwood, A. \& Price, L. (2005). Learners and learning in the twenty-first century: what do we know about students... Studies in Higher Education, 30(3), p.18.

[4] Chen, R. (2010). Investigating models for preservice teachers' use of technology to support student-centered learning. Computer and education, 55, 32-42.

[5] Park, S.Y. (2009). An analysis of the technology acceptance model in understanding university student's behavioural intention to use e-learning. Educational Technology \& Society, 12 (3), 150-162.

[6] Wong, S.L., \& Teo, T. (2009). Investigating the technology acceptance among student teachers in Malaysia: An application of the technology acceptance model (TAM). The Asia-Pacific Education Researcher, 18(2), 261-272.

[7] Teo, T., \& Schaik, P.V. (2009). Understanding technology acceptance in preservice teachers: A structural equation modelling approach. The Asia Pacific Education Research, 18(1), 47-66.

[8] Davis, F. D., (1993). User acceptance of information technology: system characteristics, user perceptions and behavioral impacts. International Journal of Man-machine Studies, 38(3), pp.475-487.

[9] Dunn-Rankin, P., 2004. Scaling methods. Lawrence Erlbaum.

[10] Davis. J.A. (1971). Elementarv survey analvsis. Englewood, NJ: Prentice-Hall.

[11] Park, S.Y. (2009). An analysis of the technology acceptance model in understanding university student's behavioural intention to use e-learning. Educational Technology \& Society, 12 (3), 150-162.

[12] Mazen, Q., Haitham, A., Ja'far, A. \& Mohammad, A. (2013). Factors Influencing the Adoption of E-Learning in Jordan: an Extended TAM Model. European Journal of Business and Management, 18(5), pp. 84-100. 
[13] Teo, T., Lee, C. B., \& Chai, C. S. (2008). Understanding pre-service teachers' computer attitudes: Applying and extending the technology acceptance model. Journal of Computer Assisted Learning, 24(2), 128-143.

[14] Teo, T. (2012). Examining the intention to use technology among pre-service teachers: an integration of the Technology Acceptance Model and Theory of Planned Behavior. Interactive Learning Environments, 20(1), 3-18.

[15] Shin, D. H. \& Kim, W. Y. (2008). Applying the Technology Acceptance Model and flow theory to cyworld user behavior: implication of the Web2.0 user acceptance. CyberPsychology \& Behavior, 11(3), pp.378-382. 